\title{
Medullary sponge kidney presenting with hypokalaemic paralysis
}

\author{
K. S. A. JAYASINGHE* \\ M.B.B.S. \\ R. MOHIDEEN \\ M.B.B.S. \\ M. H. R. SHERIFF \\ M.B.B.S., M.D.(Ceylon), \\ M.R.C.P.(UK)
}

\author{
B. L. J. MENDIS \\ M.B.B.S.
}

R. EKANAYAKE

M.B.B.S

K. DHARMADASA

M.B.B.S., M.D.(Ceylon),

F.R.C.P.(Lond), F.R.C.P.(Edin)

University Medical Unit, University of Colombo, Sri Lanka

\begin{abstract}
Summary
Medullary sponge kidney associated with a defect in urine acidification is rare and usually of no clinical significance. We report a case presenting as hypokalaemic paralysis due to associated congenital distal renal tubular acidosis.
\end{abstract}

KEY WORDS: quadreparesis, renal, tubular acidosis.

\section{Introduction}

Medullary sponge kidney is a congenital disease in which the renal medulla is replaced by numerous small cysts. The patients are usually asymptomatic. Those with symptoms usually present with renal or ureteric colic, haematuria and polyuria (Black and Jones, 1979). A few cases with impaired urinary acidification have been reported (Deck, 1965; Grandberg, Layergren and Theve, 1971; Morris et al., 1965), but the associated mild impairment of urinary concentration or acidification is of no clinical concern in the majority of patients (Yendt, 1982).

Here we report a case of medullary sponge kidney with impaired urinary acidification and potassium wasting who presented with hypokalaemic paralysis.

\section{Case report}

A 26-year-old male was admitted to the neurosurgical unit of the General Hospital Colombo in June 1979 with a history of weakness of the lower limbs which spread rapidly within $24 \mathrm{hr}$ to involve the upper limbs. He had flaccid areflexic quadreparesis

\footnotetext{
*Present address: Department of Medicine, Bristol Royal Infirmary, Bristol.
}

without sensory involvement. The higher cerebral functions, cranial nerves and ophthalmoscopy were normal and there was no bladder involvement. The cardiovascular system, respiratory system and the abdominal examinations were normal.

Despite normal cerebrospinal fluid, he was treated with dexamethasone on a clinical diagnosis of ascending myelitis. The recovery was complete within 48 hr. In July 1979, he had a similar episode which also apparently responded to dexamethasone.

In September 1979 he was admitted with rapid onset of quadreparesis with associated dyspnoea. Routine biochemical screening revealed a serum potassium of $2.2,2.3$ and $2.8 \mathrm{mmol} / 1$ at different intervals with electrocardiographic features suggestive of hypokalaemia. He recovered rapidly with parenteral and oral potassium. Biochemical investigations revealed sodium $140 \mathrm{mmol} / \mathrm{l}$, potassium (as above), chloride $112 \mathrm{mmol} / \mathrm{l}$, standard bicarbonate $17.9 \mathrm{mmol} / 1$, urea $5 \mathrm{mmol} / 1$, creatinine $120 \mu \mathrm{mol} / 1$, creatinine clearance (Feb. 1981) $110 \mathrm{ml} / \mathrm{min}, 24 \mathrm{hr}$ urinary calcium $7 \cdot 0 \mathrm{mmol}$.

On a single occasion a centrifuged sample of urine showed $20-30$ pus cells and $2-3$ red blood cells per high power field, but repeated microscopic examinations were normal and the urine was sterile on culture. No albuminuria or glycosuria was detected. Potassium balance studies were carried out on a 20 mmol sodium and a $20 \mathrm{mmol}$ potassium diet. The serum potassium varied between 3.1 and $3.4 \mathrm{mmol} / \mathrm{l}$ on the 4 consecutive days while the excretion of potassium in the urine over $24 \mathrm{hr}$ on these four occasions were $52,44,31$ and $49 \mathrm{mmol}$. This showed an inability to conserve potassium despite its restriction in the diet. During an ammonium chloride 
loading test, $(0 \cdot 1 \mathrm{~g} / \mathrm{kg}$ body weight), the urine $\mathrm{pH}$ never fell below 6.5 in spite of an arterial blood $\mathrm{pH}$ of $7 \cdot 25$. Urine osmolality after water deprivation to effect a loss in body weight of 3\%, was $307 \mathrm{mOsm} / \mathrm{kg}$ (normal-greater than $800 \mathrm{mOsm} / \mathrm{kg}$ ) suggesting a defect in urinary concentration. Tests using vasopressin were not done. A plain X-ray of the abdomen showed evidence of renal medullary calcification, and intravenous urography showed large kidneys, with a number of pyramidal cavities. The contrast filled these cavities before filling the calyces. Residual filling of the cavities occurred even after the calyces were empty, and there was an increase in the number of radiodense opacities in the pyramids in comparison to the plain X-ray. The calyceal pattern and the rest of the urinary tract were normal. These radiological features are characteristic of medullary sponge kidney (Black and Jones, 1979). The renal arteriogram did not reveal a tumour in the suprarenals and was normal.

Thus our patient had radiological evidence of medullary sponge kidneys with an impaired urinary acidification and excessive urinary potassium loss. He was commenced on oral sodium bicarbonate, $1 \mathrm{~g}$ three times a day, and advised to take a generous intake of high potassium-containing foods. No supplementary potassium was prescribed.

After commencing on this regimen he has been completely asymptomatic. His repeat urogram did not show any change in the calcific opacities.

\section{Discussion}

Medullary sponge kidney is essentially a radiological diagnosis (Beeson, Mcdermott and Wyngaarden, 1979) and can be associated with congenital defects such as renal tubular acidosis (RTA) or acquired tubular dysfunction from long standing urinary tract infection or obstructive uropathy due to nephrolithi- asis. Deck (1965) reported three patients with medua lary sponge kidneys who had renal tubular acidosis

Our patient had diagnostic radiological feature and an impaired ability to acidify urine with ammonium chloride load, with acidosis, suggestive of distal renal tubular acidosis. Excessive wasting \&f potassium in the urine probably caused the presente tion of hypokalaemic paralysis. Though this could tie an acquired defect, the absence of a history sugges tive of a chronic urinary tract infection, the presence of sterile urine on repeated examinations, and th lack of deterioration over the observed 2 years are against this possibility. The defect in urinary concentration could be a result of the hypokalaemdg nephropathy.

\section{Acknowledgments}

We would like to thank Dr T. Jayawardena, Consultant in chare of the SICU, for referring this patient to us and to $\mathrm{Mr} \mathrm{P}$. Amarasekara and Mr S. A. D. K. P. Suraweera for their assistancem the laboratory investigations of this patient and to Mrs S. Fernang8 for typing the manuscript.

\section{References}

BeEson, P.B., MCDERmott, W. \& WyngaARden, J.B. (1979) Cec $\overrightarrow{\text { }}$ Loeb Text book of Medicine, p. 1455. 15 edn. (Asian edn.) Saunders Company, Igaku Shoin Ltd., Tokyo.

BLACK, D. \& JONES, M.F. (1979) Renal Diseases, p. 252, 4thąd Blackwell Scientific Publications, Oxford.

DECK, M.D.F. (1965) Medullary sponge kidney with renal tubul acidosis. A report of 3 cases. Journal of Urology, 94, 330.

GrandberG, P.O., Layergren, C. \& TheVe, N.O. (1971) Ren角 function studies in medullary sponge kidney. Scandinavion Journal of Urology and Nephrology, 5, 177.

Morris, R.C. Jr., Yamauchi, H., Palubinskas, A.J. \& Howe STINE, J. (1965) Medullary sponge kidney. American Journal Medicine, 38, 883.

YENDT, E.R. (1982) Medullary sponge kidney and nephrolithiast. (Editorial) New England Journal of Medicine, 306, 1106. 